Animal Reproduction Research Institute, ARC, Giza, Egypt

\title{
BLOOD BIOCHEMICAL AND HORMONAL CHANGES IN POSTPARTUM BUFFALOES WITH SOME REPRODUCTIVE DISORDERS DURING HOT SEASON
}

(With 2 Tables)

\author{
By \\ MANAL, G.FADLALLAH; SAMIRA, A.EMARA; \\ A. H. ALY and M.N.S. SAKRAN \\ (Received at 14/6/1999)
}

التغير ات الكيميائية و الهرمونية في فترة ما بعد الولادة لأناث الجاموس

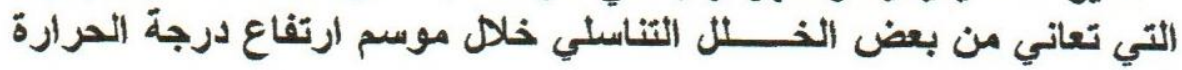

منال جله فضل الله ، سمبيرة أحمد عمارة ، أبين حسن علي، محمد نجيب سعد سكران إنان

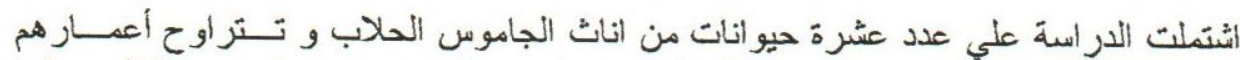

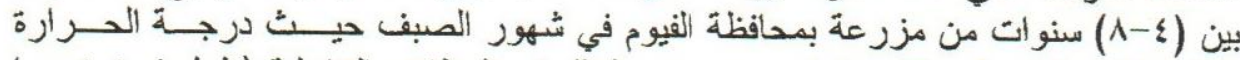

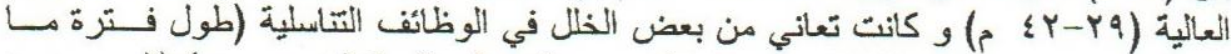

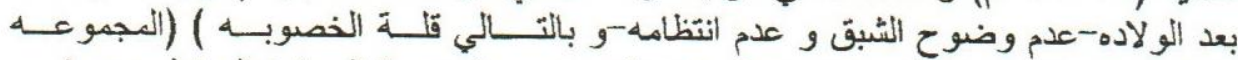

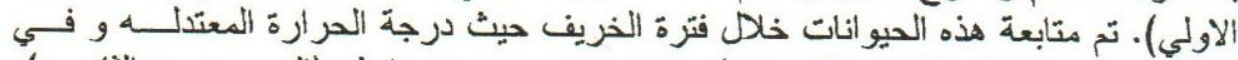

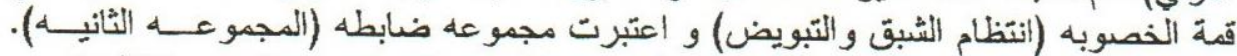

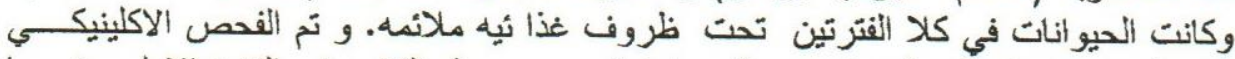

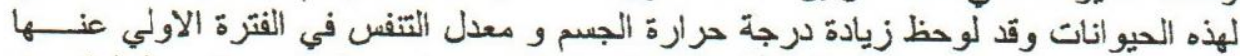

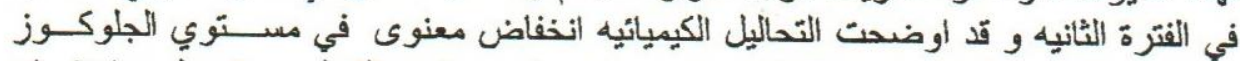

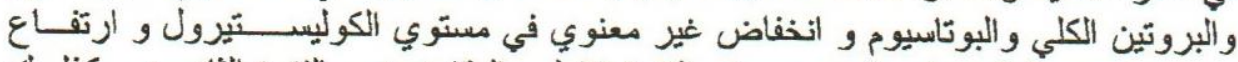

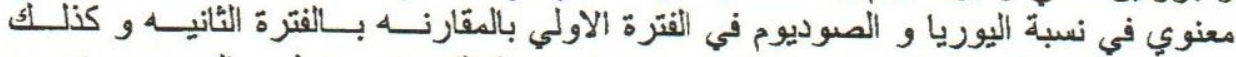

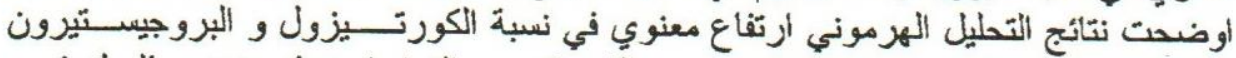

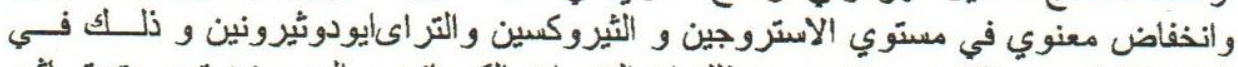

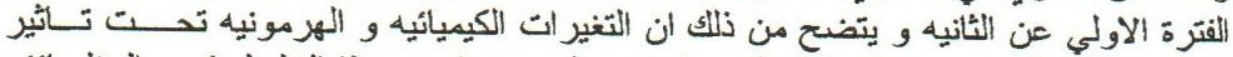

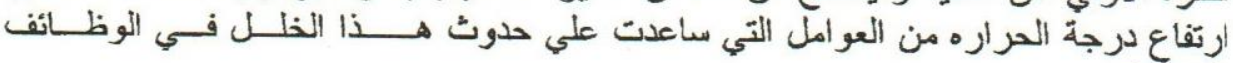




\section{SUMMARY}

This work was carried out on ten apparently healthy lactating buffaloes (4-8 years) belonging to a farm in EL-FAYOM province in hot summer months $\left(39-42^{\circ} \mathrm{C}\right)$, and fall season. The animals were considered as two groups, the first group (10 animals) were under effect of environmental heat stress and has some reproductive disorders (long postpartum period, unobserved heat, irregular estrous and delayed conception rate). The second group; the control one, were those animals of the first group but in fall season used in their maximum reproductivity and under suitable ambient environment. The clinical examination indicated increase in respiration rate and rectal temperature in the first group than the second one while the rectal examination showed ovarian inactivities in the animals under stress. On the other hand, biochemical serum analysis showed significant decrease in glucose, total proteins and potassium, insignificant decrease in cholesterol but there were significant elevation in urea and sodium concentrations. The serum hormonal assay revealed significant increased in cortisol and progesterone, insignificant decrease in estrogen and observed decrease in both triiodothyronin (T3) and thyroxine (T4) levels. It is concluded that the endocrinological and biochemical alterations indicate that elevated environmental temperature stressed those animals leading to these reproductive disorders.

Key words: Biochemical, Hormonal, Postpartum Buffaloes.

\section{INTRODUCTION}

Hot weather causes environmental heat stress in buffaloes although effects are more severe in hot climates. Buffaloes in areas with relatively moderate climates also are exposed to periods of heat stress (Armstrong, 1994) which disturbs normal reproductive cyclicity. Deviations in hormonal patterns are noted. Clinical and biochemical manifestations brought about by these changes, when ambient temperature above thermoneutrality, lead to discomfort and reduce feed intake which again depress reproduction (Spain and Spiers, 1995). Since reproduction is the ultimate measure of an animal, ability to adapt to an ever changing external milieu as well as forming the basis of life time productivity as long as the stressful events remains a challenge, the 
animal will be under stress (Coubrough, 1985) reflecting on females as delayed ovulation, a shortened less intense estrous, reduce conception rate, irregular estrous cycle, changed metabolic rate, increase respiration rate, increase body temperature and reducing feed intake (Britt et al., 1983).

The present study was designed for evaluating the effect of hot summer (environmental heat stress) on some blood biochemical parameters and hormones reflecting on reproductive behavior of lactating buffaloes in postpartum period.

\section{MATERIAL and METHODS}

\section{Animals:}

The present investigation was based on field studies of 10 apparently healthy, parasitic-free lactating buffaloes belonging to a farm in El-FAYOM province. They were thermal stressed in hot summer months and has some reproductive disorders (as unobserved heat, long postpartum period and delayed conception), they were considered as the first group (heat stressed animals). These were followed up and used in their maximum reproductivity at suitable ambient temperature in the fall season and considered as the second group (control animal). All used animals were under the same nutritional system.

\section{Measurements of behavioral patterns:} rate.

Clinical examination included rectal temperature and respiration

Rectal examination was carried for estrous detection as measured by the presence of follicles.

Serum blood samples were taken from the first group every two weeks during hot summer season (40 samples) and once during fall season (10 samples).

Biochemical analysis: Blood serum glucose, total protein, urea and cholesterol were determined using reagent kits (BioMerieux, MarcyLE toile, France). Serum sodium and potassium were determined by flame photometer (Oser, 1965).

The hormonal profile tests: For determination of cortisol, progesterone, estrogen, triiodothyronine (T3) and thyroxine (T4) were measured by direct radioimmunoassay (RIA) using coat A-count kit (Diagnostic Products Corporation) DPC. These methods have been 
characterized and verified to measure each hormone with an extrimly low cross reactivity to other hormones.

Statistical analysis:

It was carried out according to (Snedecor and Corchran, 1982).

\section{RESULTS and DISCUSSION}

The animal and it's environment form a system in which both act on and react to each other, high sensible temperature and humidity are associated with seasonal declines in reproductive efficiency (Dupreez et.al., 1992). The effect of thermal stress on reproduction is manifested in several physiologic mechanisms and includes debilitating effects on duration and expression of estrous (Drost and Thatcher, 1987).

Clinical measurements revealed increase in rectal temperature $\left(39-42^{\circ} \mathrm{C}\right)$ and respiratory rates $(38 \mathrm{Resp} . / \mathrm{min}$.) compared with buffaloes in thermal comfort state, These data parallel other results (Mohamed, 1997) which could be due to that the animal and it's environment form a system in which both act on and react to each other (Dupreez et al., 1992), an additional explanation was the effect of released adrenaline and nor-adrenaline during heat stress (Carlson, 1994), also heat stress has direct effect on heart muscle and respiratory center increasing the respiratory rates (Blood et al., 1994).

Rectal examination showed that these animals under stress were free from gynaeological diseases other than ovarian inactivities.

Regarding biochemical changes the results reported in this study (Table, 1) revealed significant decrease in glucose levels in stressed animals which could be attributed to the effect of thermal stress in altering the absolute requirements for specific nutrients by affecting the physiological processes and metabolism or by reducing total diet consumption, in lactating dairy buffaloes the dry matter begins to decline and therefore heat generated during body metabolism and in maintaining heat balance( Beede and Collier, 1986). On the other hand, thermal stress may produce a direct negative effect on appetite center of the hypothalamus (Baile and Forbes, 1974). Also the decrease of glucose level may be due to the increased respiratory rate which lead to rapid utilization of blood glucose by respiratory muscles (Hycel, 1973). Total protein level showed a significant decrease in buffaloes under heat stress often have negative nitrogen balances because of reduced intakes, hence, less protein is available for productive functions (Huber et al., 1994). 
Also, the reduced energy consumption and increased maintenance requirements during heat stress often results in considerably more protein being metabolized to meet energy requirements of buffaloes than that metabolized at moderate temperature (Beede and Collier, 1986).

Serum urea revealed significant elevation in buffaloes during heat stress, it could be attributed to that this stress disrupts homeostasis of dairy buffaloes caused by evoking regulatory reactions which try to maintain heat balance (Beede and Collier, 1986) and as a results of negative function of acid-base regulation and also alteration in antiduretic hormones, water, electrolyte turn over, a major adaptation to thermal stress is peripheral vasodilatation and increased blood flow to accommodate evaporative and convective heat loss (Thatcher and Collier , 1982) concomitantly reduced blood flow to internal organ systems such as kidneys and reproductive tract (Roman Ponce et al., 1978). Another explanation isthat serum urea elevation may be due to that there was concomitant break down of tissues during gluconeogenesis under effect of increased cortisol (Payne, 1987).

Table 1: Some blood biochemical changes during post-partum in heat stressed and normal buffaloes

\begin{tabular}{|l|l|l|}
\hline \multicolumn{1}{|c|}{ Parameters } & \multicolumn{1}{|c|}{$\begin{array}{c}\text { Group I } \\
\text { (heat stress) } \\
\mathbf{n = 4 0}\end{array}$} & $\begin{array}{l}\text { Group II } \\
\text { ( control ) } \\
\mathbf{n = 1 0}\end{array}$ \\
\hline Glucose(mg\%) & $48.72 \pm 2.2^{*}$ & $56.86 \pm 2.5$ \\
\hline Total protein (g\%) & $10.3 \pm 0.23^{*}$ & $11.21 \pm 0.26$ \\
\hline Urea (mg\%) & $18.57 \pm 0.88^{*}$ & $15.52 \pm 0.86$ \\
\hline Potassium (mEq./L) & $3.61 \pm 0.15^{* * *}$ & $5.55 \pm 0.23$ \\
\hline Sodium (mEq./L) & $154.15 \pm 1.5^{*}$ & $148.3 \pm 2.1$ \\
\hline Cholesterol $(\mathbf{m g} \%)$ & $93.92 \pm 5.2$ & $101.43 \pm 4.76$ \\
\hline
\end{tabular}

Values are means \pm S.E.

$*=\mathrm{P}<0.05$

The results showed significant decrease in serum potassium levels and significant increase in serum sodium which could be related to the relationship among heat stress and plasma aldosterone which controls the reabsorption of sodium and excretion of potassium, hyperactivity of the adrenal cortex and increased production of aldosterone occur during heat stress results in excessive reabsorption of sodium and urinary excretion of potassium (David and Cole, 1986). 
Total cholesterol results showed insignificant decrease in heat stressed buffaloes which could be due to the increased lipid metabolisms and the conversation of cholesterol into bile acids and other substances and activation lipoprotein lipase (Capen and Martin, 1989), another explanation that ACTH stimulate steroidogenesis which hydrolyze cholesterol esters stored in lipid droplets and liberated which converted by numbers of enzymes to cortisol (Loraine and Trevor, 1976).

It is necessary to identify the mechanisms by which stress disrupts normal reproduction, the neuroendocrine regulation of follicular development and ovulation requires a complex and delicate interplay between the pituitary gonadotropins and feed back actions of the major follicular steroids, the stress induced secretion of adrenal glucocorticoids, these steroids can affect both synthesis and secretion of gonadotropins (Gary, 1991), the results in Table (2) showed that significant increase in progesterone and cortisol which could be due to the adrenal axis responded to stress by initiating secretion of corticotropin-releasing hormone from neurosecretory neurons in the hypothalamus, this peptide act upon the pituitary corticotropins to stimulate the secretion of adrenocorticotrophic hormone (ACTH) which in turn act on the adrenal cortex to stimulate the synthesis and secretion of adrenal cortical steroids glucocorticoids and progesterone (Moberg, 1987), these steroids account for the majority of the biological changes with respect to reproduction, there is evidence that the glucorticoids can act on all components of the gonadal axis, the secretion of gonadotrophic releasing hormones ( $\mathrm{Gn} \mathrm{RH}$ ), the release of gonadotropins, and the synthesis of gonadal steroids (Dobson, 1987), initial cortisol rise with subsequent depression, raised progesterone levels, changes in leutinizing hormone $(\mathrm{LH})$, cortisol blocks the preovulatory secretion of leutinizing hormone (LH) (Li and Wagner, 1983), also it was shown that the high cortisol in plasma at the days of exposure to heat stress may indicate an acute responsive adrenocortical function due to stimulation of peripheral thermoreceptors in the skin resulting in activation of adrenocorticotrophic hormone (ACTH) releasing mechanisms in the hypothalamus (Wagner et al., 1972). It is clear that heat stress has acute effects due to altered endocrine states and feed back mechanism of hypothalamus-pituitary- adrenal axis, the glucocorticoids have comparable inhibitory effect on the basal release of LH and FSH (Gary, 1991). Among the hormones associated with thermal stress are thyroxine (T4) and triiodothyronine (T3), the observation reported in our 
study indicated that significant decreased levels of both hormones which could be attributed to that the elevated temperature reduces the thyroid activity leading to decrease thyroxine which was also influenced by amount of feed intake (McGuire et al., 1991), production and release of thyroxine by the thyroid gland is controlled by the anterior pituitary gland through it's thyroid stimulating hormone (Swanson and Miller, 1972), there is interrelationship between ovarian function and hypothalamo-pituitary-thyroid axis, also there is considerable evidence that the thyroid plays a role in the regulation of reproductive activity (Shi and Barell, 1994). Thyrotrophic stimulating hormone (TSH) influences reproduction via the production of thyroxine and triiodothyroxine which regulate the metabolic pools of nitrogen producing available energy necessary for the reproductive system (Magdub et. al., 1982 ).

Finally it could be concluded that stress control may be the key stone for the herd health reproductivity, owing to the direct and indirect unfavorable consequences of endocrine and biochemical responses ranging from discomfort to infertility. So management strategies to reduce the effects of heat stress may be in the form of physical modifications of the environment such as shade, ventilation and cooling, nutritional management schemes such as less forage and increase nutrient density in the diet.

Table 2: Some hormonal changes during post-partum in heat stress and normal buffaloes

\begin{tabular}{|l|l|l|}
\hline \multicolumn{1}{|c|}{ Parameters } & \multicolumn{1}{|c|}{$\begin{array}{c}\text { Group I } \\
\text { (Heat stress) } \\
\mathbf{n = 4 0}\end{array}$} & $\begin{array}{c}\text { Group II } \\
\text { (Control ) } \\
\mathbf{n = 1 0}\end{array}$ \\
\hline Cortisol (Ug/dL.) & $9.14 \pm 1.51^{*}$ & $4.62 \pm 1.04$ \\
\hline Progesterone (ng/ml.) & $3.1 \pm 0.56^{* *}$ & $0.95 \pm 0.1$ \\
\hline Estrogen (Pg/ml.) & $11.54 \pm 2.0^{*}$ & $19.46 \pm 2.3$ \\
\hline Triiodothyronine(ng/dL) & $130.5 \pm 5.6^{*}$ & $146.34 \pm 4.02$ \\
\hline Thyroxine Ug/dL & $2.88 \pm 0.29^{*}$ & $3.97 \pm 0.41$ \\
\hline
\end{tabular}

Values are means + S.E.

$*=\mathrm{P}<0.05 \quad * *=\mathrm{P}<0.01 \quad * * *=\mathrm{p}<0.00$ 


\section{REFERENCES}

Armstrong, D.V. (1994): Heat stress interaction with shade and cooling J. Dairy sci.77:2044-2050.

Baile, C.A. and Forbes J.M. (1974): Control of feed intake and regulation of energy balance in ruminants. Physiol.Rev. 54:160.

Beede, D.K. and Collier, R.J. (1986): Potential nutritional strategies for intensively managed cattle during thermal stress. J.Anim.Sci. 62:543-554.

Blood, D.C., Radostitis, O.M. and Gay, C.C. (1994): "Veterinary medicine". A text book of the diseases of cattle, sheep, pigs, goat and horses. $8^{\text {th }}$. Ed. The English book society and Bailler Tndall, LTd., London.

Britt. J.H., Szarek, V.E. and Levis, D.G. (1983): Characterisation of summer fertility of swos in large confinement units. Theriogenology,20,133-140.

Capen, C.C. and Martin, S.L. (1989): The thyroid gland: "In Veterinary Endocrinology and Reproduction" McDonald, L.E. and Pineda, M.E. (ED), $4{ }^{\mathrm{TH}}$ Edition, leas Febiger, pp 66-68.

Carlson, N.R. (1994): Physiology of behavior . $5^{\text {th }}$.Ed Allyne and Bacon, Boston.U.S.A.

Coubrough, R.I. (1985): Stress and fertility. A review. Onderstepoort.J.vet.Res., 52:153-156.

David, P.H. and Cole, N.A. (1986): Management of transit-stress syndrome in cattle : Nutritional and Environmental Effects. J.Anim.Sci. 62:555-560.

Dobson, H. (1987): Effect of transport stress on luteinizing hormone released by Gn.RH. in dairy cows. Acta Endocnol. (copenh), 115:63-66.

Drost, M. and Thatcher, W.W. (1987): Heat stress in dairy cows. Veterinary Clinic of North America,Food animal practice, 3:609-618.

Dupreez, J.H., Willemse, J.J.C. and Van Ank, H. (1994): Effect of heat stress on conception in dairy herd model in the Natal high lands of South Africa. Onderstepoort Journal of Veterinary research,61:1-6. 
Dupreez, J.H., Gieseck, W.H., Barnard, M.L.; Erasmus, A and Hattingh, A.G. (1992): Heat stress in dairy cattle and other live stock under South Africa conditions. Pretoria: Departement of Agricultural Development (Technical Communication; no. 234.

Gary, H.P. (1991): How behavioral stress disrupts the endocrine control of reproduction in domestic animals. J.Dairy Sci. 74:304.

Huber, J.T., Higginbotham, G., Gomez-Alarcon, R.A., Taylor, R.B., Chen, K.A., Chan, S.C. and Wu, Z. (1994): Heat stress interactions with protein, supplemental fat and fungal cultures. J.Dairy Sci. 77:2080-2090.

Hycel, Inc. (1973): Chemistry methodology references manual, Hycel Inc., Houston, T.X.

Li, P.S. and Wagner, W.C. (1983): Effect of hyper adrenal states on lutinizing hormone in cattle. Biol. Reprod. 9: 11-24.

Loraine, J.A. and Trevor, E.B.(1976): Hormones assay and their clinical applications. $4^{\text {th }} . E d$. Chuchil livingstone Edinburgh London and New-York.

Magdub, H., Johnson, H.D. and Belyea, R.L. (1982): Effect environmental heat and dietary fiber on thyroid physiology of lactating cows.J.Dairy Sci. 65:2323-2331.

McGuire, M.A., Beed, D.K., Collier, R.J., Buonomo, F.C.D., Delorenzo, M.A., Wilcox, C.j, Huntington,G.H. and Reyonlds,C.K.(1991): Effects of outer thermal stress and amount of feed intake on conceptions of somatotropin, insulin-like growth factor (IGF)-I and (IGF)-II, and thyroid hormones in plasma of lactating Holestein cows. J.Anim.Sci. 69:2050-2056.

Moberg, G.P. (1987): Influences of adrenal axis upon the gonads. Oxford Rev.Reprod. Biol. 9: 456-496.

Mohamed, S.S.M (1997): Effect of some stress factors on milk production of Friesian cows. Ph.D.Thesis.

Oser, B.L. (1965): Hawk's physiological chemistry $14^{\text {th. }}$ Ed MCGrawhill.

Payne, J.M. (1987): "The metabolic profile test." Latimer, Trendand Co. LTd.,Plymouth.

Roman-Ponce, H., Thatcher. W.W., Canton, D., Barron, D.H. and Wilcox C.T. (1978): Thermal stress effect of uterine blood flow in dairy cows. J.Anim.Sci. 46:175. 
Shi, Z.D. and Barell, G.K. (1994): Thyroid hormones are required for expression of seasonal changes in deer (Cervuselaphus). Reprod.Feril.Dev, 6: 187-192.

Snedecor, G.W. and Corchran, W.C. (1982): "Statistical methods". $7^{\text {th }}$.Ed. The Lowo univ.press. Ames Lowo, U.S.A.

Spain, J.N. and Spires (1995): Effect of supplemental shade on thermoregulatory response of calves to heat challenge in hutch environment. J. Dairy sci.79: 639-646.

Swanson, E.Wl and Miller, J.K. (1972): Problems in estimating thyroxine secretion rates in cattle. J.Dairy Sci. 59:

Thatcher, W.W. and Collier (1982): "Effect of heat on animal productivity." Hand book Agriculturral productivity. M.Richcigl, Ed.CRC press, Boca Raton, FL.

Wagner, W.C. (1983): In vivo and in vitro studies on the effect of adrenocortico-trophic hormone or cortisol on the pituitary response to gonadotropin releasing hormone. Biol Reprod., 29: 25-37.

Wagner, W.C., Strohbehan, R.E. and Harris, P.A. (1972): Corticoids and luteal function in heifers. J. Anim. Sci. 35: 709. 